\title{
HORMONAL CHANGING DURING PREGNANCY AND LACTATION OF NEW ZEALAND WHITE FEMALE RABBITS.
}

\author{
Nagwa, A. Ahmed ${ }^{1}$, A.A. Azoz, ${ }^{2}$, Amina, F. Khadr², M.M. El-Shafie ${ }^{1}$ \\ 1- Animal Production Department, Faculty of Agriculture, Cairo University, Giza, \\ Egypt, 2- Rabbit Breeding Department, Animal Production Research Institute, Dokki, \\ Giza, Egypt
}

\section{SUMMARY}

A total number of 30 does and 6 bucks of mature New Zealand White (NZW) rabbits weighting $3.0-3.5 \mathrm{~kg}$ and aging 6-7 months were used in the present study. Does were divided according to post partum interval of mating (next to the first parity) into three groups, each of 10 does. Does in groupl (G1) were re-mated through the first day following parturition as an intensive production, does in group 2 (G2) were re-mated on the day $14^{\text {th }}$ post partum as a semi-intensive production and those in group3 (G3) were re-mated on the day $30^{\text {th }}$ postpartum (after weaning) as an extensive production.

Blood samples were collected for hormones determination (progesterone, estradiol, prolactin and triiodothyronine) directly before mating and at 7, 14, 21 and 28 days through pregnancy. During lactation period, blood samples were withdrawn after parturition and at 7, 14, 21 and 28 days of lactation. Progesterone $\left(P_{4}\right)$ concentration in serum of the NZW female rabbits significantly increased form parturition up to 7 days of pregnancy and maintained the high level up to 21 days, then a slight decrease was deserved at 28 days of pregnancy. The highest level of $P_{4}$ was found in females of (G3) during pregnancy and females of (G2) during lactation. The level of estradiol $\left(E_{2}\right)$ in the serum of NZW female rabbits gradually increased from 14 to 21 days of pregnancy, then significant increase was found at 28 days of pregnancy. The highest level of $\left(E_{2}\right)$ was determined in females of $(G 2)$ during pregnancy and lactation.

There were no significant differences in prolactin hormone (PRL) concentrations due to re-mating interval. Lower and higher levels of (PRL) were recorded in females of (G3) during pregnancy and lactation period, respectively. The highest level of triiodothyronine hormone $\left(T_{3}\right)$ was determined in females of $(G 3)$ during pregnancy and lactation period.

It could be concluded that pregnant rabbits may regulate the hormonal pattern according to their physiological status requirements.

Keywords: Rabbit, hormones, pregnancy, lactation

\section{INTRODUCTION}

Remating interval is one of the most important items in the managerial regimes since it is a limiting factor of the success in the conception rate for each of parity, consequently the sequences of parities within a given period (Azoz, 1996; Khadr, et al., 1996 and Azoz 2001). Commercial rabbit breeding aims at having more litters

Issued by The Egyptian Society of Animal Production 
per year. This intensive rabbit production requires more studies of their behavior and physiological function particularly in the field of reproduction.

The stress imposed upon the doe by pregnancy is less than that of lactation (Hafez, 1970). On the other hand, Partridge et al. (1984) reported that there was an adverse effect of suckling on implantation, which varied directly according to the number of suckling, strains and environmental conditions.

Steroid hormones are the major agents which control success of pregnancy, litter size and effective lactation (Ahmed Nagwa et al., 1994; Azoz, 1996; Ahmed Nagwa et al., 2000 and Azoz 2001). The profile of these hormones is expected to be affected by the rearing schemes.

The objective of this work was to study the effect of post partum remating intervals on hormonal profile of NZW does rabbits during pregnancy and lactation periods.

\section{MATERIALS AND METHODS}

This study was carried out in the Rabbit Unit, Center of Agricultural Production Technology, Faculty of Agriculture, Cairo University. The hormonal assay was executed in the laboratory of Animal Production Research Institute, Agriculture Research Center, Ministry of Agriculture.

\section{Animal:}

A total number of 30 does and 6 bucks of mature New Zealand White Rabbits (NZW) weighting $3.0-3.5 \mathrm{~kg}$ and aging 6 - 7 months were used in this experiment. The doe was transferred to the buck's cage at the time of service. Mating of the doe was executed twice to bucks of proven fertility. Pregnancy was diagnosed by abdominal palpation at 14 days post service. Before the beginning of the experimental does were mated almost at the same date to test the reproductive efficiency of the foundation stock in their first parity. All the does (30) were of good fertility thus treated as the experimental design for remating.

Does were divided according to post-partum interval of mating (next to the first parity) into three groups. Does in group 1 (G1) were remated through the day following parturition (intensive production), does in group 2 (G2) were remated on the $14^{\text {th }}$ day post-partum (semi-intensive production) and does in group 3 (G3) were remated on the $30^{\text {th }}$ day post-partum, after weaning (extensive production).

\section{Blood samples and hormonal assay:}

Blood samples were withdrawn from the marginal ear vein, directly before mating and at 7, 14, 21 and 28 days through pregnancy. During lactation period blood samples were withdrawn after parturition and at 7, 14, 21 and 28 days of lactation.

Serum samples were prepared by centrifugation ( $3000 \mathrm{rpm}$ for 15 minutes) and stored at $-18^{\circ} \mathrm{C}$ until hormonal assay. Progesterone $\left(\mathrm{P}_{4}\right)$, estradiol $\left(\mathrm{E}_{2}\right)$, prolactin $(\mathrm{PRL})$ and triiodothyronine $\left(\mathrm{T}_{3}\right)$ were determined using radioimmunoassay (RIA) technique.

Ready antibody coated tube kits (Orion Diagnostic, Finland) were used to determine $\mathrm{P}_{4}$. According to the manufacturer information, antiserum at $50 \%$ displacement, has cross reaction values $100 \%$ with progesterone, while the reaction is less than $3.9 \%$ with pergnenolone and less than $1 \%$ with any of the other steroids. 
The standard curve of progesterone ranged between 0.0 and $40.0 \mathrm{ng} / \mathrm{ml}$. Sensitivity value when assaying $100 \mathrm{ml}$ of plasmas is about $0.08 \mathrm{ng} / \mathrm{ml}$.

Estradiol $\left(\mathrm{E}_{2}\right)$ antibody (at $50 \%$ binding) has $100 \%$ cross reaction with estradiol while it is $4.4 \%, 10.0 \%$ and $1.8 \%$ with d-equilenin, estrogen and estrone- $\beta$ glucuronide and ethinyl estradiol, respectively. It was less than $1.0 \%$ with any of the steroids.

Total triiodothyronine $\left(\mathrm{T}_{3}\right)$ antiserum is highly specific for triiodothyronine. The cross reactivity to total $\mathrm{T}_{3}$ antiserum was $100 \%$ with $\mathrm{T}_{3}$, while it was $19.8 \%$ and $1.1 \%$ with triiodothyroacetic acid and D-thyroxine, respectively. It was less than $1 \%$ with any of the other natural compounds that might be present in the samples.

Data were statistically analyzed using ANOVA procedure SAS (1988) as 2 factor-factorial arrangement of treatment with the model including effects of remating intervals (1, 14 and 30 days post-partum). And days through pregnancy or lactation $(0,7,14,21$ and 28 days). Differences among means were tested using Duncan Multiple Range Test (Duncan, 1955).

\section{RESULTS AND DISCUSSION}

\section{Progesterone hormone:}

\subsection{During pregnancy}

A clear trend of serum $\mathrm{P}_{4}$ concentration was determined during pregnancy with different systems of remating interval (Table, 1 and Fig., 1). Sharp significant increase occurred in $\mathrm{P}_{4}$ concentration after mating up to 7 days of pregnancy (Table 1) and this increase continued up to 21 days, then slight decrease occurred at 28 days (the end of gestation).

Table 1. Effect of remating interval on serum progesterone concentration $(\mathrm{ng} / \mathrm{ml})$ of $\mathrm{NZW}$ rabbits during pregnancy and lactation stages $(\mathrm{SE}=\mathbf{0 . 0 3 0 2})$

\begin{tabular}{lccccc}
\hline \multirow{2}{*}{$\begin{array}{c}\text { Remating } \\
\text { intervals }\end{array}$} & \multicolumn{5}{c}{ Pregnancy stages } \\
\cline { 2 - 6 } mating day & $\mathbf{7}$ days & $\mathbf{1 4}$ days & $\mathbf{2 1}$ days & 28 days \\
\hline 14 days & $1.297^{\mathrm{c}}$ & $6.400^{\mathrm{ab}}$ & $8.040^{\mathrm{a}}$ & $7.843^{\mathrm{ab}}$ & $7.113^{\mathrm{ab}}$ \\
30 days & $1.020^{\mathrm{c}}$ & $6.057^{\mathrm{b}}$ & $7.303^{\mathrm{ab}}$ & $7.053^{\mathrm{ab}}$ & $6.853^{\mathrm{ab}}$ \\
& $0.987^{\mathrm{c}}$ & $6.373^{\mathrm{ab}}$ & $8.520^{\mathrm{a}}$ & $8.137^{\mathrm{ab}}$ & $7.413^{\mathrm{ab}}$ \\
\cline { 2 - 6 } & \multicolumn{5}{c}{ Lactation stages } \\
$\mathbf{1}$ day & $7.771^{\mathrm{a}}$ & $1.700^{\mathrm{de}}$ & $1.029^{\mathrm{de}}$ & $2.038^{\mathrm{d}}$ & $1.403^{\mathrm{de}}$ \\
$\mathbf{1 4}$ days & $6.549^{\mathrm{b}}$ & $0.773^{\mathrm{e}}$ & $1.144^{\mathrm{de}}$ & $5.307^{\mathrm{c}}$ & $6.541^{\mathrm{b}}$ \\
$\mathbf{3 0}$ days & $7.184^{\mathrm{ab}}$ & $1.325^{\mathrm{de}}$ & $1.140^{\mathrm{de}}$ & $0.740^{\mathrm{e}}$ & $0.721^{\mathrm{e}}$ \\
\hline
\end{tabular}

abcde Means within the same row having different superscripts differ significantly $(\mathrm{P}<0.05)$. 


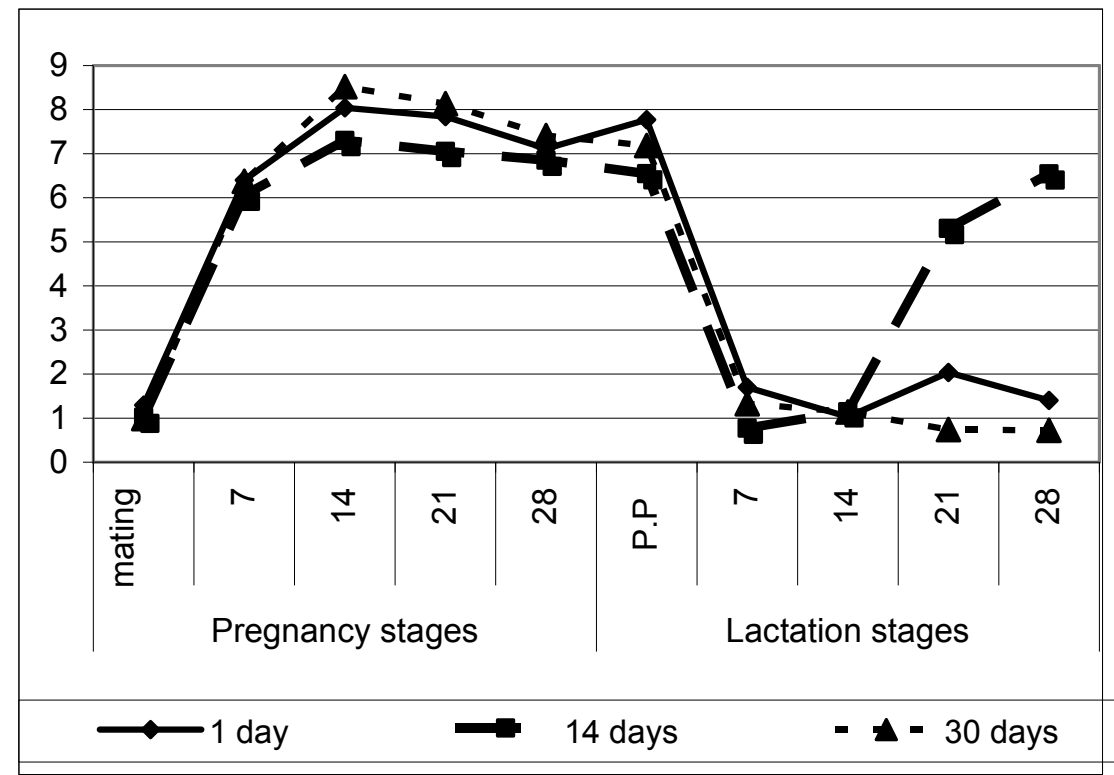

Figure 1. Effect of remating interval on serum progesterone concentration $(\mathrm{ng} / \mathrm{ml})$ of NZW rabbits during pregnancy and lactation stages.

The present mean peripheral serum $\mathrm{P}_{4}$ concentration is similar to those previously reported for pregnant rabbits by (Challis et al., 1973; Stoufflet and Caillol, 1988; Ahmed Nagwa et al., 1994; Azoz, 1996; Khadr et al., 1996 and Azoz, 2001). The highest mean concentration of circulating $\mathrm{P}_{4}$ was observed around days 12-14 followed by a gradual decline between mid pregnancy and parturition. Also, in the present study, the changes in peripheral serum $\mathrm{P}_{4}$ levels in pregnant NZW rabbits are in harmony with the results of Khadr et al. (1996). They reported that the $\mathrm{P}_{4}$ curve of pregnancy could be divided into three phases: (a) increasing phase, from coitus up to day 7-14 or 11 of pregnancy, (b) phase of maintenance from day 14 to day 21 of pregnancy and (c) phase of regression where values of the hormone decreased to become minimal on days 30,31 and 33 of gestation (depending upon gestation length). The findings of McNitt (1992) support our results. He reported that plasma $\mathrm{P}_{4}$ levels rose rapidly during the first trimester of pregnancy, remained relatively constant during the second trimester and declined through the final trimester.

The high level of $\mathrm{P}_{4}$ during the $1^{\text {st }}$ half of pregnancy plays a role in the preparation of the uterus for implantation of the fertilized ovum and the inhibition of uterine contractions during the first few days of pregnancy (Habeeb and El-Masry, 1991 and Ahmed et al., 1994). In addition, high $\mathrm{P}_{4}$ concentration and particular estrogen titer shut off Lutinizing hormone release from the pituitary gland and prevent induced ovulation during pregnancy in rabbits (Hafez, 1970 and Sharma, 1979). Moreover, progesterone suppresses the immunological rejection of the fetuses (Daniel et al., 1984). The fall in $\mathrm{P}_{4}$ titer in late pregnancy is the first step in the 
initiation of parturition, where prostaglandin participate in later stages of parturition by expelling fetuses through their oxytocin property (Enbergs, 1979).

In the present study $\mathrm{P}_{4}$ concentration was higher in cases of does mated at 30 days after parturition since there were no interference of milking. The $1^{\text {st }}$ day post-partum mated group had a confound effect of pregnancy and lactation than in case of does mated on 14 day post-partum which had halfway interloping effect of pregnancy and lactation.

However these differences in $\mathrm{P}_{4}$ levels were not statistically significant (Table 1). The insignificant differences in the level of $\mathrm{P}_{4}$ when females were mated at different periods post-partum may be related to the level of prolactin hormone during lactation which stimulate $\mathrm{P}_{4}$ secretion from corpora lutea. Daniel et al. (1984) and Younglai (1986) reported that prolactin was essential for $\mathrm{P}_{4}$ secretion and acted as an essential hormone in rabbit uterine response to $\mathrm{P}_{4}$ by modulation of $\mathrm{P}_{4}$ receptor activity for maintenance of pregnancy period.

It could be concluded that remating interval post-partum had no significant effect on the level of progesterone hormone throughout pregnancy.

\subsection{During lactation:}

Table (1) shows different patterns of $\mathrm{P}_{4}$ hormone concentration after parturition (throughout lactation) in the three systems of remating intervals. In the first system, when does were introduced to the buck on the $1^{\text {st }}$ day after parturition, the concentration of $\mathrm{P}_{4}$ hormone in serum was high just after parturition, a significant low level was found at 7 days from the beginning of lactation and continued up to 14 days (Figure 1). The level of hormone increased slightly at 21 days and decreased again when it was determined at 28 days from lactation.

In the second system, of does remated on the $14^{\text {th }}$ day after parturition, the level of $\mathrm{P}_{4}$ significantly $(\mathrm{P}<0.05)$ decreased drastically at 7 days followed by a negligible increase till the $14^{\text {th }}$ days (at the next mating). Then it continued to increase up to 28 days (the first half period of the following pregnancy). At the third system of mating (when does were remated at 30 day after parturition, after weaning) the level of $\mathrm{P}_{4}$ significantly continued to decrease after parturition up to 28 days after that.

The significant fall in the level of serum $\mathrm{P}_{4}$ after parturition up to 14 days postpartum in the three cases of remating interval indicates that the regression in $\mathrm{P}_{4}$ level in the first group may be attributed to induction of the next litter which leads to an increased secretion of GnRH, thus FSH and $\mathrm{LH}$, and resulted in a larger crop of follicles that could develop for the next cycle (McNitt 1992). However, the second reason of falling $\mathrm{P}_{4}$ level in the serum of does which observed in the three groups may be attributed to the depression effect of lactation.

After 14 days of lactation, it could be observed that the highest level of $\mathrm{P}_{4}$ hormone was detected in serum of does remated at 14 days post-partum (G2, Figure 1). This result indicates that $\mathrm{P}_{4}$ level increased significantly after mating for maintaining the following pregnancy. The level of the hormone in the serum of does in the first group (after 14 days during lactation) was lower than those of group 2, this result may be related to the inhibition of $\mathrm{P}_{4}$ in the second stage of pregnancy. 


\section{Estradiol $\left(E_{2}\right)$ :}

\subsection{During pregnancy:}

The effect of remating interval on estradiol $\left(\mathrm{E}_{2}\right)$ concentration in serum of NZW female rabbits through pregnancy is shown in Table (2) and Figure (2). Fluctuating trend was determined for the concentration of $\mathrm{E}_{2}$ hormone from mating to 21 days of pregnancy, then, significant increase was observed at 28 days of pregnancy. The differences in serum estradiol hormone level due to remating interval were not significant from after mating to 21 days of pregnancy, however, these differences were significant at 28 days of pregnancy (Table 2). At that stage, the level of $\mathrm{E}_{2}$ was significantly higher in the serum of females mated at 14 days post-partum than females mated within the $1^{\text {st }}$ day after parturition and females mated at 30 days postpartum (after weaning), respectively (Figure 2). These results are in agreement with those obtained by Stouffelt and Coillol (1988). Also, these results are consistent with the results of Ubilla and Rebollar (1994), they found that $E_{2}$ levels was high from 5 to 7 and 23 to 30 days post-partum. These authors attributed the failure of receptive mating on day 14 post-partum to low estradiol levels.

Table 2. Effect of remating interval on serum estradiol concentration $(\mathrm{pg} / \mathrm{ml})$ of NZW rabbits during pregnancy and lactation stages $(\mathrm{SE}=1.792)$

\begin{tabular}{lccccc}
\hline Remating & \multicolumn{5}{c}{ Pregnancy stages } \\
\cline { 2 - 5 } interval & mating day & $\mathbf{7}$ days & $\mathbf{1 4}$ days & $\mathbf{2 1}$ days & 28 days \\
\hline 1 day & $4.507^{\mathrm{c}}$ & $8.130^{\mathrm{c}}$ & $4.057^{\mathrm{c}}$ & $9.267^{\mathrm{c}}$ & $38.010^{\mathrm{b}}$ \\
$\mathbf{1 4}$ days & $2.657^{\mathrm{c}}$ & $9.173^{\mathrm{c}}$ & $6.557^{\mathrm{c}}$ & $11.450^{\mathrm{c}}$ & $57.690^{\mathrm{a}}$ \\
30 days & $4.307^{\mathrm{c}}$ & $8.563^{\mathrm{c}}$ & $5.630^{\mathrm{c}}$ & $14.070^{\mathrm{c}}$ & $31.790^{\mathrm{b}}$ \\
\cline { 2 - 6 } & \multicolumn{5}{c}{ Lactation stages } \\
1 day & $7.459^{\mathrm{bc}}$ & $6.543^{\mathrm{c}}$ & $6.122^{\mathrm{cd}}$ & $7.491^{\mathrm{bc}}$ & $7.900^{\mathrm{abc}}$ \\
$\mathbf{1 4}$ days & $7.038^{\mathrm{c}}$ & $4.652^{\mathrm{de}}$ & $6.446^{\mathrm{c}}$ & $9.174^{\mathrm{ab}}$ & $9.516^{\mathrm{a}}$ \\
30 days & $7.526^{\mathrm{bc}}$ & $6.847^{\mathrm{c}}$ & $2.619^{\mathrm{f}}$ & $2.872^{\mathrm{f}}$ & $4.228^{\mathrm{ef}}$ \\
\hline
\end{tabular}

abcdef Means within the same row having different superscripts differ significantly (P $<0.05)$.

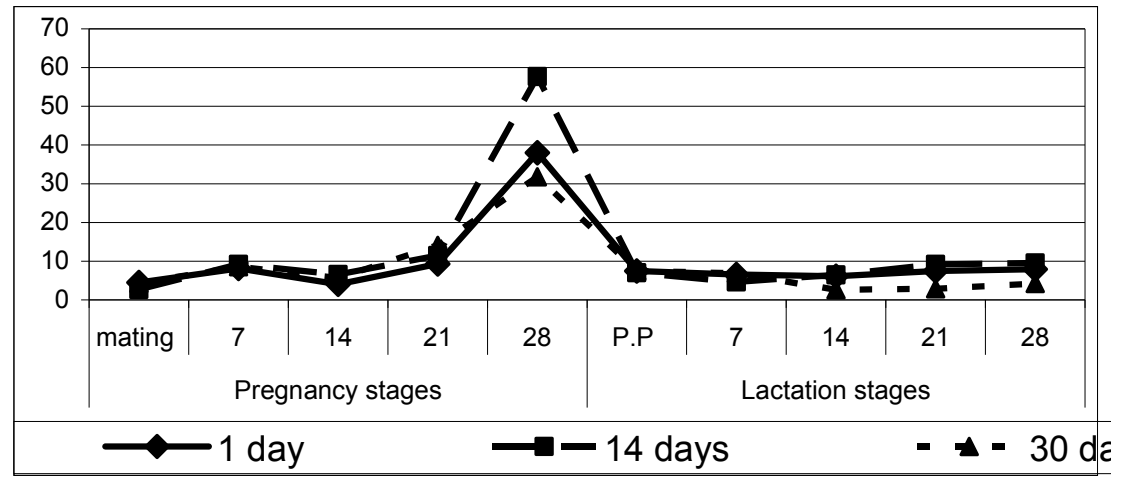

Figure 2. Effect of remating interval on serum estradiol concentration $(\mathrm{pg} / \mathrm{ml})$ of NZW rabbits during pregnancy and lactation stages 
The increased serum estradiol concentration in pregnant rabbits at day 7 postpartum is, probably, related to the follicular growth and increase of the follicle steroidogenic activity that occurred between the last days of pregnancy and between 5-9 days post-partum (Diaz et al., 1988) as well as, to the high plasma FSH levels observed around 5-7 days after parturition in lactating rabbits (Ubilla et al., 1992).

It is interesting to point out that the level of $E_{2}$ hormone was high on the $1^{\text {st }}$ day after parturition in serum of does mated within that day as well as that left milking to be mated after 30 days, being about two folds of that remated after 14 days postpartum (Table 2 and Figure 2). This drop in the concentration at mating on the $14^{\text {th }}$ day seems to be brought about by the halfway of lactation as present in case of lactation proper (will no pregnancy) in G3 (Table 2). This high concentration in G1 and G3 coincides with the rise of sexual receptivity (high natural conception rate) which was observed in females remated at 1 and 30 days post-partum, in the present study. As mentioned above, Ubilla and Rebollar (1994) stated that the failure of receptively on day 14 post-partum is due to low estradiol concentration.

\subsection{During lactation:}

The results of changes in peripheral blood of $E_{2}$ hormone throughout lactation stage are shown in Table (2) and Figure (2). It can be observed that similar trends of $\mathrm{E}_{2}$ concentration was obtained in serum of does remated at first day and 14 days postpartum during lactation period, however, the level of $E_{2}$ hormone was higher in the first group than in those of the second group through the 7 days of lactation followed by opposite trend. This result may be attributed to the immediately remating after parturition in the first group leading to follicular growth and increasing the level of $\mathrm{E}_{2}$ hormone, while the ovulation and follicular growth were occurred at 14 days postpartum in the second group leading to more increase of $E_{2}$ level in serum of does in group two than those of group one (Figure 2). Due to remating at 30 days after parturition the level of $\mathrm{E}_{2}$ hormone in this group significantly $(\mathrm{P}<0.05)$ decreased after 7 days post-partum and contended to the end of lactation (Table 2 and Figure 2). The differences in $\mathrm{E}_{2}$ level due to remating interval were significant throughout the lactation period.

\section{Prolactin hormone:}

3.1. During pregnancy:

The effect of remating intervals on PRL hormone concentration of NZW does serum during pregnancy is shown in Table (3) and Figure (3).

Remating intervals had no significant effect on the concentration of PRL hormone (Table 3). The overall average of concentration was almost similar being 2.107, 2.089 and $2.093 \mathrm{ng} / \mathrm{ml}$ in serum of does remated at 1,14 and 30 days post-partum, respectively.

Similar trend was determined for PRL hormone concentration during pregnancy in does remated on 1 day and 30 days post-partum (Figure 3). The level of PRL hormone decreased after mating at 7 days of pregnancy, sharply in group 3, followed by increase up to 21 day of pregnancy, then remarkable decrease was observed at 28 days of pregnancy. However, in group 2, does mated at 14 days post-partum, the level of prolactin hormone increased from mating to 7 days, then it decreased gradually up to 28 days of pregnancy (Figure 3 ). 
Table 3. Effect of remating interval on serum prolactin concentration $(\mathrm{ng} / \mathrm{ml})$ of NZW rabbits during pregnancy and lactation stages $(\mathrm{SE}=\mathbf{0 . 2 2 5 2})$

\begin{tabular}{lccccc}
\hline Remating & \multicolumn{5}{c}{ Pregnancy stages } \\
\cline { 2 - 6 } interval & mating day & $\mathbf{7}$ days & 14 days & $\mathbf{2 1}$ days & 28 days \\
\hline 1 day & 2.203 & 2.130 & 2.167 & 2.163 & 1.873 \\
14 days & 2.123 & 2.203 & 2.110 & 2.057 & 1.953 \\
30 days & 2.217 & 1.900 & 2.073 & 2.217 & 2.057 \\
\cline { 2 - 6 } & \multicolumn{5}{c}{ Lactation stages } \\
$n_{\text {1 day }}$ & $2.408^{\mathrm{ab}}$ & $1.918^{\mathrm{b}}$ & $1.941^{\mathrm{b}}$ & $2.163^{\mathrm{ab}}$ & $2.163^{\mathrm{ab}}$ \\
$\mathbf{1 4}$ days & $2.251^{\mathrm{ab}}$ & $1.991^{\mathrm{ab}}$ & $2.108^{\mathrm{ab}}$ & $1.868^{\mathrm{b}}$ & $2.041^{\mathrm{ab}}$ \\
30 days & $2.512^{\mathrm{a}}$ & $1.939^{\mathrm{b}}$ & $2.072^{\mathrm{ab}}$ & $2.217^{\mathrm{ab}}$ & $2.056^{\mathrm{ab}}$ \\
\hline
\end{tabular}

ab Means within the same row having different superscripts differ significantly $(\mathrm{P}<$ $0.05)$.

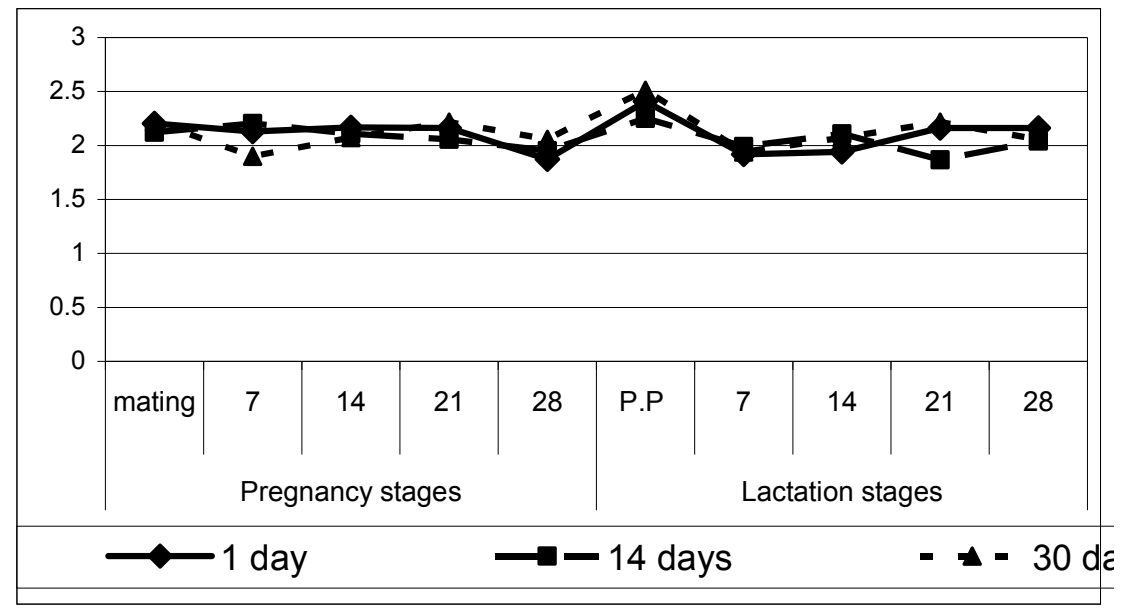

Fig. 3. Effect of remating interval on serum prolacten concentration $(\mathrm{ng} / \mathrm{ml})$ of NZW rabbits during pregnancy and lactation stages

The slight decrease in serum PRL concentration observed from 21 days to 28 days of pregnancy, may be responsible for the high magnitude of LH and FSH associated with high sexual receptivity. Forcada and Abecia (1990) reported that in early pregnancy female receptivity decreased but was higher a few days before parturition. McNitt (1992) reported that at the time of mating, there was a fall in plasma PRL levels which rose to precopulatory levels in about 30 minutes. Plasma levels were again increased significantly three to four days post-coitus and remain elevated for the first half or two thirds of gestation after which the levels declined. Lamb et al. (1991) reported that does which failed to ovulate when served at 14 days post-partum had reduced plasma concentration of estradiol 17- $\beta$ and prolactin.

The changes in levels of prolactin in the present study with different mating systems were related to doe physiological status, the number of bunnies suckling and the stage of lactation. Daniel (1984) reported that the principle function of PRL 
during pregnancy was to conserve the amount of $\mathrm{P}_{4}$ available for maintenance of pregnancy.

\section{2. during lactation:}

The effect of remating interval on serum PRL hormone concentration of NZW rabbits throughout lactation is shown in Table (3) and Figure (3).

There were no significant changes observed in the levels of PRL hormone during the different stages studied through lactation. The mean value of the hormone level was $2.390,1.949,2.040,2.083$ and $2.087 \mathrm{ng} / \mathrm{ml}$ after parturition and at 7, 14, 21 and 28 days of lactation, respectively.

Generally, the level of PRL hormone decreased after parturition to 7 days. In G1, remated 1 day post-partum slight decrease was terminated at 14 days of lactation and the level of the hormone gradually and slightly increased up to 28 days of pregnancy (Table 3 and Figure 3). The level of PRL throughout lactation was higher in G3 $(2.160 \mathrm{ng} / \mathrm{ml})$ than that in females of G1 $(2.132 \mathrm{ng} / \mathrm{ml})$ or those in $\mathrm{G} 2(2.032 \mathrm{ng} / \mathrm{ml})$. This result explains the important role of PRL in certain aspects of maternal behavior.

\section{Triiodothyronine hormone:}

\subsection{During pregnancy:}

The effect of remating interval after parturition on $\mathrm{T}_{3}$ concentration $(\mathrm{ng} / \mathrm{ml})$ during pregnancy is shown in Table (4) and Figure (4).

Table 4. Effect of remating interval on serum triiodothyronene concentration $(\mathrm{ng} / \mathrm{ml})$ of NZW rabbits during pregnancy and lactation stages $(\mathrm{SE}=\mathbf{0 . 0 8 5})$

\begin{tabular}{lccccc}
\hline Remating & \multicolumn{5}{c}{ Pregnancy stages } \\
\cline { 2 - 6 } interval & Mating day & $\mathbf{7}$ days & $\mathbf{1 4}$ days & $\mathbf{2 1}$ days & $\mathbf{2 8 ~ d a y s}$ \\
\hline $\mathbf{1}$ day & $0.850^{\mathrm{f}}$ & $1.927^{\mathrm{bcd}}$ & $2.187^{\mathrm{abc}}$ & $1.587^{\mathrm{cde}}$ & $1.523^{\mathrm{de}}$ \\
$\mathbf{1 4}$ days & $1.193^{\mathrm{ef}}$ & $1.760^{\mathrm{bcde}}$ & $1.633^{\mathrm{cde}}$ & $2.593^{\mathrm{a}}$ & $1.497^{\mathrm{de}}$ \\
$\mathbf{3 0}$ days & $1.920^{\mathrm{bcd}}$ & $2.273^{\mathrm{ab}}$ & $1.903^{\mathrm{bcd}}$ & $2.197^{\mathrm{abc}}$ & $1.420^{\mathrm{def}}$ \\
\cline { 2 - 6 } & \multicolumn{5}{c}{ Lactation stages } \\
$\mathbf{1}$ day & $1.8846^{\mathrm{b}}$ & $1.1309^{\mathrm{i}}$ & $1.5139^{\mathrm{f}}$ & $1.4172^{\mathrm{g}}$ & $1.7327^{\mathrm{c}}$ \\
$\mathbf{1 4}$ days & $1.0981^{\mathrm{i}}$ & $1.1931^{\mathrm{h}}$ & $1.4470^{\mathrm{g}}$ & $1.7217^{\mathrm{c}}$ & $1.5784^{\mathrm{de}}$ \\
$\mathbf{3 0}$ days & $1.5190^{\mathrm{ef}}$ & $1.8810^{\mathrm{b}}$ & $2.0358^{\mathrm{a}}$ & $1.5350^{\mathrm{ef}}$ & $1.6041^{\mathrm{d}}$ \\
\hline abcdefghi & & &
\end{tabular}

abcdetghi Means within the same row having different superscripts differ significantly $(\mathrm{P}<0.05)$.

Fluctuated trend of $T_{3}$ was detected during pregnancy. The overall mean of $T_{3}$ concentration in serum of G3 was higher than that of those G2 or G1. It was 1.943, 1.735 and $1.615 \mathrm{ng} / \mathrm{ml}$, respectively. 


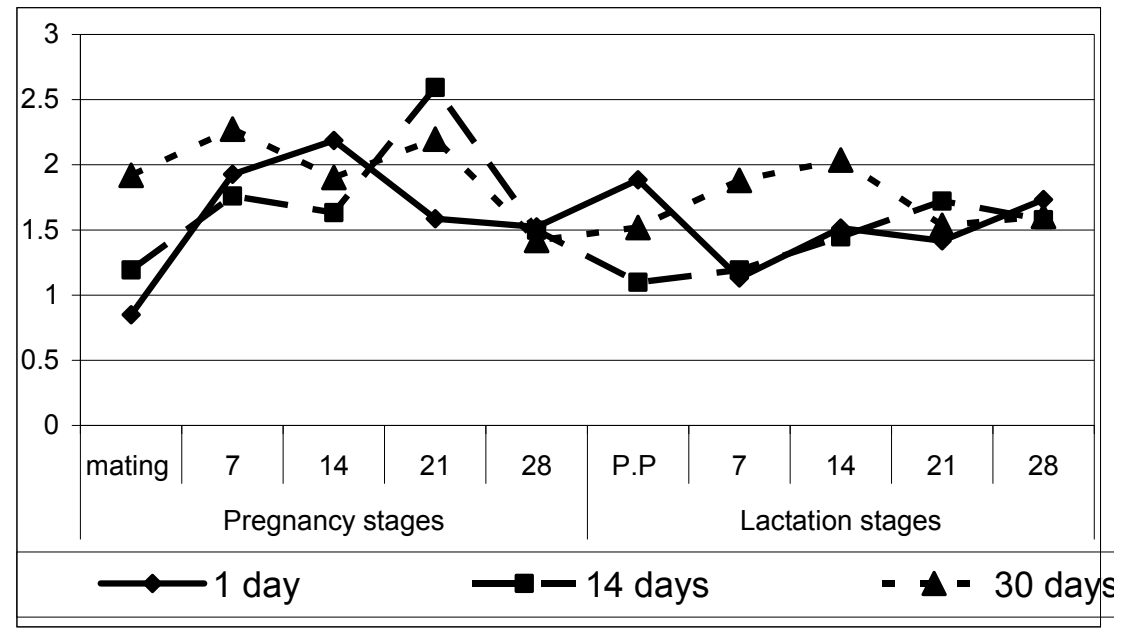

Figure 4. Effect of remating interval on serum triiodothyronine concentration $(\mathrm{ng} / \mathrm{ml})$ of NZW rabbits during pregnancy and lactation stages

Similar fluctuating trend was observed in $\mathrm{T}_{3}$ hormone concentration of group 2 and group 3 (Figure 4), that the level of the hormone increased significantly after mating up to 7 days of pregnancy (Table 4), then it significantly decreased at 14 days and significant increase was determined at 21 days of pregnancy followed by a sharp significant drop at 28 days (the end of pregnancy). However, the level of $\mathrm{T}_{3}$ hormone in serum of G1 significantly increased from mating to 7 days after parturition and continued up to 14 days (Table 4 and figure 4), then significant decrease was detected in the second half of pregnancy (from 14 to 28 days). Bober et al. (1980) reported that thyroid hormones are considered necessary for cellular metabolism of the mammary gland and energy utilization which may be an important factor in fetal development during pregnancy and milk biosynthesis.

The increase in $T_{3}$ level in pregnant rabbits may be due to its role in tissue synthesis, especially, in the first half of pregnancy (Habeeb and El-Massry, 1991) and development of fetuses. The increase in $\mathrm{T}_{3}$ concentration in the second half of pregnancy indicates its vital role in energy metabolism to face milk synthesis.

\subsection{During lactation:}

Significant changes in the level of $\mathrm{T}_{3}$ hormone were determined (Table 4) throughout lactation. Due to remating interval post-partum, females of G3 had the highest level of $\mathrm{T}_{3}$ hormone along 21 days throughout lactation. However, the level of $\mathrm{T}_{3}$ decreased sharply after parturition in the group $\mathrm{G} 1$ and increased gradually from 7 up to 28 days of lactation (Figure 4). In group 2, the level of $\mathrm{T}_{3}$ increased after parturition until 21 days of lactation, then a decrease was detected 28 days of lactation.

The results belong to the effect of remating intervals on $T_{3}$ concentration in serum indicate that rabbits try to regulate the concentration of hormone according to 
physiological status to face the requirements of pregnancy only or lactation only or pregnancy and lactation at the same time.

It could be concluded that pregnant rabbits may regulate the hormonal pattern according to their physiological status requirements.

\section{REFERENCES}

Ahmed Nagwa, A., Amina, F. Khadr, M.M. Shafei and A.A. Azoz, 1994. Effect of post-partum mating interval of rabbits on progesterone level through pregnancy. Egyptian J. Anim. Prod., 31(suppl.): 463.

Ahmed Nagwa, A., A.H. Barkawi, A. Ismail and E.M. Abd-El-Kafy, 2000. Effect of vitamin $\mathrm{E}$ on ovarian activity, embryonic mortality and productive performance of NZW rabbits during summer season. J. Agric. Sci. Mansura Univ., 25 (8) : 5579 .

Azoz, A. A., 1996. Effect of different mating systems on reproductive and productive efficiency of rabbits. M. Sc. Thesis, Fac. of Agric., Cairo Univ., Egypt.

Azoz, A.A., 2001. Effect of remating interval on reproductive and productive performance of rabbits. Ph. D. Thesis. Fac. of Agric., Cairo Univ., Egypt.

Bober, M.A., A. Dollah, B.A. Becker and H.D. Johnson, 1980. The influence of exogenous T3 on plasma prolactin, T3, TSH and milk production during heat stress in Holstein cows. J. Anim. Sci., 55 : 339.

Challis, R.G., I.J. Davis and K.J. Ryan, 1973. The concentration of progesterone, estrone and estradiol-17B in the plasma of pregnant rabbits. Endocrin., 93: 971.

Daniel, J.C., A.E. Jetton and B.S. Chilton, 1984. Prolactin as a factor in the uterine response to progesterone in rabbits. J. Reprod. Fert., 72: 442.

Diaz, P., J.M. Rodriguez, L. Gosalvez and M. Romen, 1988. Cyclic ovarian activity in post-partum rabbits. J. Appl. Rabbit. Res., $10: 122$.

Duncan, D.B., 1955. Multiple range and multiple F-test Biometrics, 11 : 1-24.

Enbergs H. 1979. Radioimmunological investigations on the level of progesterone in the peripheral blood of pregnant rabbits with referance to season and number of young. Borliner and Miinchener Tierarzttiche Wochernschrift, 92 :32-34.

Forcada, F. and J.A. Abcia, 1990. Circulating progesterone levels, ovulation rate and sexual behaviour in rabbits during seudopregnancy induced by vasectomized males and HCG injection. J. Appl. Rabbit Res., 13 : 74-79.

Habeeb, A.A. and K.A.EI-Masry, 1991. Hormonal pattern in pregnant rabbits and some productive aspects as affected by litter size at birth. Egypt J. Poult. Sci.,1 $1: 429$.

Hafez, E.S.E., 1970. Reproduction and Breeding Techniques for Laboratory Animals. Lea and Feebiger, Philadelphia, U.S.A.

Khadr, Amina, F., Nagwa, A. Ahmed and A. A. Azoz, 1996. Effect of post-partum mating interval on reproductive and productive performance of rabbits. Egyptian J. Anim. Prod., 33 (suppl.): 389-401.

Lamb, I.C., W. Strachan, G. Henderson, T. Atkinson, W. Lawson, G.G. Partridge, M.F. Fuller and P.A. Racey, 1991. Effects of reducing the remating interval after parturition on the fertility and plasma concentrations of lutenizing hormone, prolactin, oestradiol-17 $\beta$ and progesterone in lactating domestic rabbits. J. Reprod. Fert., 92: 281. 
McNitt, J.I., 1992. Endocrinological, approaches for commercial rabbit production. J. Appl. Rabbit Res., $15: 364$.

Partridge, G.G., S.J.Allan, M.Findlay and W. Corrigall, 1984. The effects of reducing the remating interval after parturition on the reproductive performance of the commercial doe rabbit . J.Anim. Prod., 39: 465.

SAS, 1988. SAS procedures guide. Release 6.03 Edition, SAS Institute Inc., Cary, NC, U.S.A.

Sharma, S.C., 1979. Temporal changes in PGE, PGE-O, Oestradiol-17a and progesterone in uterine venous plasma and endometrial of rabbits during early pregnancy. Proceedings of the International Symposium on Prostaglandins and Reproductive Physiology, Montpellier.

Stoufflet, I. and M. Caillol, 1988. Relation between circulating sex steroid, pregnancy and postpartum in the domestic rabbit. J. Reprod. Fert., $82: 209$.

Ubilla, E. and P.G. Rebollar, 1994. A study on the evolution of sexual receptivity and plasma Estradiol-17 $\beta$ levels throughout the lactation period, in rabbits. Proceeding of the first international conference held in Cario, Egypt, vol. 8, 1994: 377.

Ubilla, E., J.M.R. Alvarino, A. Esquifino and C. Agrasal, 1992. Effect of induction of parturition by administration of a prostaglandin F2 alpha analogue in rabbits: possibe modification of prolactin, LH and FSH secretion patterns. Anin. Reprod. Sci., $27: 13$.

Younglai, E.V., 1986. Age-related changes in the concentrations of serum gonadotropins and cholesterol in the female rabbit. J. Endocrin., 109: 278 
التغيرات الهرمونية أثناء الحمل والرضاعة فى إناث الأرانب

نجوى عبد الهادى أحمد'، أبو بكر أحمد عزوز ‘، أمينة فوزى خضر ‘، محمد محمود الثافعى'

1 - قسم الإتتاج الحيوانس، كلية النزاعة، جامعة القاهة، الجيزة، r - قسم بحوث تريية الأرانب، معطج بحوث

الإنتاج الحيوانس، دقى، الجيزة.

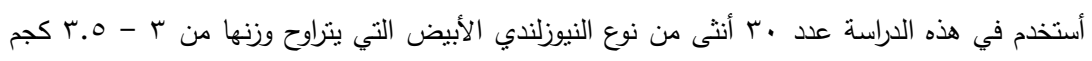

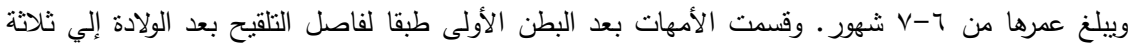
مجاميع كالثالي:

المجموعة الأولى: نم التلقيح فيها خلال يوم بعد الولادة (نظام الإنتاج المكثف)، المجموعة الثانية: تم التلقيح

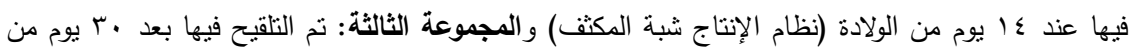
الولادة أى بعد الفطام (نظام الإنتاج الغير مكثن).

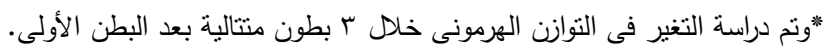
وكانت أهم التنائج المتحصل عليها هي:

ا- أعلى مستوى من تركيز هرمون البروجستيرون وجد في إناث المجموعة الثالثة أثناء الحمل و إناث

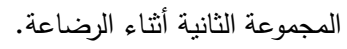

ץ- أعلى مستوى من هرمون الاستراديول وجد في الإناث التى لقحت عند ؟ أيوم من الولادة أثناء الحمل

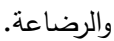
r- انخفض تركيز هرمون البرولاكتن في سيرم الإناث الملقحة بعد ·ـ يوم من الولادة (بعد الفطام) أثناء فتزرة الحمل بينما أرتقع تركيزه أثناء الرضاعة. ع- حدث ارتفاع في تركيز هرمون التراى أيودو ثيرونين في سيرم إناث المجموعة الثالثة أثناء الحمل والرضاعة.

من ننائج هذه الدراسة يمكن استنتاج ان الثنكل الهرموني لإناث الأرانب الحوامل يتحدد طبقا للحالة

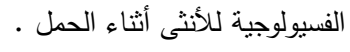

